\title{
EXPERIÊNCIA DA TRANSITORIEDADE: WALTER BENJAMIN E A MODERNIDADE DE BAUDELAIRE
}

\author{
Luciano Gatti* \\ lfgatti@gmail.com
}

\begin{abstract}
RESUMO O artigo examina a abordagem feita por Walter Benjamin da concepção de modernidade apresentada pelo poeta e crítico de arte Charles Baudelaire. Após o exame da ideia de beleza moderna nos textos de crítica de Baudelaire, são abordados os motivos da preferência de Benjamin pela apresentação da modernidade na poesia de Baudelaire, particularmente no poema alegórico "Le cygne”. Por fim, o texto enfoca a relação entre a poesia moderna de Baudelaire e a concepção de experiência de Benjamin.
\end{abstract}

Palavras-chave Walter Benjamin; Charles Baudelaire; Modernidade; Experiência.

ABSTRACT The paper investigates the approach made by Walter Benjamin of Charles Baudelaire's conception of modernity. After examining the idea of modern beauty in Baudelaire's critical texts, the reasons of Benjamin's preference for the presentation of modernity in Baudelaire's poetry are analized, particularly, in the allegorical poem "Le cygne". At last, the paper focuses on the relation between Baudelaire's modern poetry and Benjamin's concept of experience.

Keywords Walter Benjamin; Charles Baudelaire; Modernity; Experience.

* Doutor em filosofia pela Unicamp. Pós-doutorando em filosofia pela PUC/SP. Artigo recebido em maio 2008 e aprovado em 28 abr. 2009. 
Em $O$ pintor da vida moderna, texto escrito a partir de desenhos de Constantin Guys, Charles Baudelaire elabora uma noção de beleza vinculada à realidade histórica do artista, nomeada por ele de modernidade. A busca pelo belo abandona os modelos antigos e se volta para a atualidade que se apresenta ao artista capaz de apreendê-lo na fugacidade do momento presente. "Ele buscou por toda a parte a beleza passageira e fugaz da vida presente, o caráter daquilo que o leitor nos permitiu chamar de modernidade" (BAUDELAIRE, 1976b, p. 724). Baudelaire, porém, não diz apenas que os artistas modernos devem ater-se ao presente para retirar dele a sua beleza, como também que os artistas do passado só foram grandes porque fizeram o mesmo. Não só o belo é interessante, mas também o presente que o produz. Pode-se dizer assim que o belo funde-se com o histórico: "O passado é interessante não somente pela beleza que dele souberam extrair os artistas para quem ele era o presente, mas também como passado, pelo seu valor histórico. O mesmo ocorre com o presente. O prazer que obtemos com a representação do presente deve-se não apenas à beleza de que ele pode estar revestido, mas também à sua qualidade essencial de presente" (BAUDELAIRE, 1976b, p. 684).

Definindo a modernidade como uma busca pelo atual, bem como por um olhar capaz de percebê-lo na sua apresentação passageira, Baudelaire opera uma forte alteração no que se entendia tradicionalmente pela oposição entre modernidade e antiguidade. Se até então os limites entre esses dois termos pareciam certos ao indicar épocas que se contrapunham, com Baudelaire eles se tornam mais fluidos. Eles não correspondem mais a épocas distintas, e passam a designar uma relação entre o momento presente e aquele que acabou de passar. Dito de outra maneira, a oposição entre modernidade e antiguidade indica a partir de então a oposição entre o novo e o velho, entre o moderno e o antigo, inexistente antes da vinculação da modernidade ao presente transitório.

Num texto da década de 1960, o historiador da literatura Hans Robert Jauss investiga, num contexto particularmente relevante para a questão discutida aqui, a historicidade da palavra "modernidade". Segundo ele, o uso que é feito deste termo nos dias de hoje, especialmente na estética e na compreensão histórica do mundo, deriva diretamente do uso que Baudelaire fez dela em sua crítica de arte, mais explicitamente em $O$ pintor da vida moderna. Jauss salienta, no entanto, que a palavra cunhada por Baudelaire para expressar a transformação da arte no seu tempo, bem como a consciência de historicidade dessa mesma arte, é fruto de um longo desenvolvimento do adjetivo "moderno" que remonta ao século V (JAUSS, 1970, p. 12). Durante o transcorrer desse tempo, duas transformações se destacam: segundo a primeira, ao longo dos séculos houve um processo de separação entre a arte 
de um determinado período e a força que os padrões artísticos da Antiguidade representavam para ela na forma de uma exemplaridade a ser seguida; e pela segunda, correlata à primeira, o sentido de moderno desenvolve-se no interior de um processo relacionado às transformações históricas da autocompreensão de uma determinada época (JAUSS, 1970, p. 14).

Jauss aponta que a problematização da modernidade deriva de uma antiga oposição que ocorria em termos "antigo" e "moderno". O termo moderno, nesse caso, possui um uso semântico que remete à ideia de tempo presente ou de atualidade. Trata-se, porém, mais de uma oposição cronológica de uma época que se descobre em relação com a Antiguidade clássica do que a consciência de uma experiência genuinamente nova que diferenciará ou mesmo romperá a relação entre presente e passado. Mesmo em períodos como a Renascença, que apresenta uma elevada consciência de época, a distinção com relação ao período anterior só é cumprida no âmbito de uma nova relação com a Antiguidade, que continuará fornecendo as regras que a regularão, seja no plano científico ou no plano artístico. Se se pode usar o termo "modernidade" para essas épocas, é possível dizer que havia uma modernidade para cada período que se contrapunha ao anterior por uma relação diferenciada com a Antiguidade.

Em janeiro de 1687, a Querela dos antigos e modernos, realizada na Academia Francesa e introduzida por Charles Perrault, produziu uma mudança sensível nessa situação, abrindo a possibilidade ao Iluminismo francês de se inscrever como um novo começo histórico. Jauss afirma, todavia, que os modernos, mobilizados pelos avanços na filosofia e na ciência moderna desde Descartes e Copérnico, não reivindicavam para si, de modo algum, o estabelecimento de um corte temporal que daria origem a uma nova época. $\mathrm{O}$ que estava em causa era um novo relacionamento com a Antiguidade, que, no entanto, mantinha o paradigma da Antiguidade como referência para a produção artística. Os modernos reclamaram para si a categoria de verdadeiros antigos, pois se viam como a etapa final de um grande processo de realizações, do qual a Antiguidade seria apenas a infância, e o Renascimento, sua idade madura. Embora as regras que devessem governar as artes e as ciências surgissem de seu próprio tempo, a definição de moderno continuava presa a uma relação particular com a Antiguidade, vista agora na forma de uma negação. Mas nem por isso a querela fica diminuída aos olhos de Jauss. A descoberta das diferenças entre os antigos e os modernos no plano das belas artes durante o Iluminismo francês é uma das experiências marcantes das ideias de aprimoramento e progresso que dominam o período (JAUSS, 1970, p. 29-35). 
No final do século XVIII, uma nova forma de consciência de época aparece transformando a utilização da relação antigo/moderno. O romantismo, que Jauss identifica em Chateaubriand, Madame de Staël e nos irmãos Schlegel, substitui o termo de oposição "antigo" pelo "clássico" e revaloriza a Idade Média - o início do mundo cristão - em oposição à Antiguidade. Essa redescoberta não se coloca contraditoriamente ao Iluminismo, na interpretação de Jauss, mas é por ele mesmo introduzida a partir da Querelle no exame das especificidades que diferenciam o mundo moderno do mundo antigo (JAUSS, 1970, p. 40). Ao lado de considerações sobre a peculiaridade da redescoberta da Idade Média na construção de um passado nacional e sobre a manipulação do adjetivo "romântico" pela literatura na descrição de situações particulares, Jauss expõe uma nova relação com a história e também com a natureza, ambas vistas por um olhar nostálgico que salienta no passado algo que foi perdido. $\mathrm{O}$ que se coloca na distância temporal é a verdade de uma natureza à qual o homem romântico não tem mais acesso e que guarda a infância da humanidade. A história e a paisagem correspondem-se, assim, em uma relação recíproca: "a paisagem como natureza sob a forma do passado, como sensação de uma harmonia perdida com a totalidade do mundo" (JAUSS, 1970, p. 49).

Entre o Iluminismo e o Romantismo, de um lado, e a Modernidade de Baudelaire, de outro, Jauss situa a cesura temporal representada pela Revolução Francesa. Esse corte já havia sido sentido por Stendhal que, no ensaio Racine e Shakespeare, colocara a história até 1789 em forte contraste com a que lhe sucedia. Tal experiência, de que a história mudara completamente, coloca-se no início de uma consciência de época que percebeu o passo dado do velho ao novo como uma ruptura no tempo. A revolução havia cortado a linha entre presente e passado. A partir de então, o romântico deixa de ser a relação com um passado perdido e passa a ser, na definição de Stendhal, o atual, o que traz prazer às pessoas do tempo presente. Stendhal abandona o uso de romântico como conceito de época, abandonando também a antítese histórica com o classicismo. O conceito de romântico retoma a função latina originária do termo "moderno", e passa a designar o agora histórico do presente, dando ao moderno o valor mais alto e vendo no clássico apenas um valor funcional. Desta maneira, o romântico, ou o moderno, deixa de contrapor-se a um passado autoritário na forma da Antiguidade (JAUSS, 1970, p. 53).

Pode-se dizer que Stendhal colocou a questão, mas só com Baudelaire o problema apresentou-se configurado na sua amplitude: foi somente com a alteração de sentido do par antigo/moderno para velho/novo que a autocompreensão de uma certa época pôde determinar completamente as leis pelas quais se rege, ou seja, a modernidade somente pôde fundar-se como 
época própria e distinta das demais quando expulsou da dicotomia antigo/ moderno qualquer referência à Antiguidade. Esse tema é o que Jauss procura realçar na modernidade de Baudelaire tendo como texto-base $O$ pintor da vida moderna. Ali, Baudelaire realizou o que se pode chamar de um programa para a estética moderna.

Onze anos antes, contudo, no Salão de 1846, Baudelaire já esboçava uma teoria da arte moderna ao remeter ao sentido da oposição entre antigo e moderno tal como fora transformada por Stendhal. O moderno é concebido como o atual, como o novo, como algo que diz respeito exclusivamente ao tempo presente. Em outras palavras, Baudelaire está procurando a identificação do belo com o efêmero. A dualidade do belo a ser desenvolvida n'O pintor da vida moderna encontra sua primeira formulação: "Toda beleza contém, como todo fenômeno possível, algo de eterno e algo de transitório — de absoluto e de particular. A beleza absoluta e eterna não existe, ou não é mais que uma abstração extraída da superfície geral das belezas diversas. O elemento particular de cada beleza vem das paixões, e como temos nossas paixões particulares, temos nossa beleza" (BAUDELAIRE, 1976b, p. 493). Segundo essa colocação, cada época teria a sua beleza moderna. Mais do que designar um período que se contrapõe a outro, e se define por essa contraposição, Baudelaire salienta o caráter de novidade desse moderno como a expressão de sua época, a qual seria melhor representada no romantismo: "Para mim, o romantismo é a expressão mais recente, mais atual do belo" (BAUDELAIRE, 1976b, p. 420), e "Quem diz romantismo diz arte moderna" (BAUDELAIRE, 1976b, p. 421).

Apesar desses apontamentos, que indicam a elaboração de uma estética moderna, é n'O pintor da vida moderna que Baudelaire desenvolve o programa com mais acabamento. Aí é possível encontrar, no radical aprofundamento no presente transitório, uma resposta à questão de Stendhal sobre a permanência da obra moderna. Em torno de comentários sobre os desenhos de Constantin Guys, Baudelaire coloca-se contra os adeptos da arte eterna e imutável, representados pelo classicismo, formulando o que ele denomina de "teoria racional e histórica do belo": "Essa é uma bela ocasião, na verdade, para estabelecer uma teoria racional e histórica do belo, em oposição à teoria do belo único e absoluto; para mostrar que o belo apresenta sempre, inevitavelmente, uma dupla composição, ainda que a impressão que ele produza seja una" (BAUDELAIRE, 1976b, p. 685). A seguir vem a definição do belo: "O belo é feito de um elemento eterno, invariável, cuja quantidade é excessivamente difícil de determinar, e de um elemento relativo, circunstancial, que será, caso se queira, cada um a sua vez ou todos em conjunto, a época, a moda, a moral, a paixão" (Idem). 
Baudelaire funda a modernidade como uma ruptura com os padrões da antiguidade. A beleza da modernidade não se opõe à beleza antiga. O que ocorre é que a beleza antiga, o eterno e imutável, está presente na beleza moderna na forma de seu devir. Isso significa que a fugacidade da beleza moderna só poderá tornar-se eterna, e a obra de arte ser autenticamente moderna, se o artista moderno for capaz de retirar de sua época justamente aquilo que é transitório e fugidio, que é passível de tornar-se antigo e obsoleto. O transitório é o que constitui a obra como moderna e, ao mesmo tempo, o que lhe assegura a possibilidade de tornar-se eterna. Em outras palavras, o belo moderno está presente na efemeridade de um momento sujeito à ação destruidora do tempo e que tem sua única chance de sobrevivência na sua transfiguração pela obra do artista. A tensão do histórico com o eterno torna-se o tema da reflexão da estética moderna. Trata-se de autoconsciência de época radical, porque, ao identificar-se pelo novo, que no instante seguinte estará superado, a modernidade passa a reger-se por um tempo que se autoconsome. Ao mesmo tempo que a consciência da temporalidade engendra essa época, ela a ameaça, tornando os limites da separação entre antigo e moderno cada vez mais fluidos e incertos. Esse caráter até então inexistente do moderno está presente, com maior ou menor negatividade, tanto na poesia como na crítica de arte de Baudelaire.

Em seus ensaios sobre Baudelaire, escritos no final dos anos 1930, Walter Benjamin destaca esta negatividade constitutiva da temporalidade moderna, tomando-a como critério para uma avaliação do modo como Baudelaire a apresenta no conjunto de sua obra. Em outras palavras, Benjamin retoma a oposição entre antigo e novo com o intuito de apontar certa insuficiência da teoria da arte apresentada por Baudelaire em O pintor da vida moderna. A cisão apontada na noção de belo entre um elemento eterno e outro transitório não daria conta, afirma Benjamin, da forte alteração que a necessidade da busca do novo insere na apreensão do tempo. Sua conclusão a respeito da definição do belo é cortante: "Não se pode dizer que isso vá fundo na questão" (BENJAMIN, 1991b, p. 81; 1999, p. 585). Na sua interpretação, tal definição seria estática demais diante da força com que a noção de novo dissolve a separação entre modernidade e antiguidade.

Esta censura de Benjamin à teoria da modernidade de Baudelaire já foi objeto das ressalvas de comentadores. Jauss, particularmente, salienta a incompreensão por Benjamin do caráter eminentemente positivo da modernidade descoberta por Baudelaire. Jeanne Marie Gagnebin retoma esta crítica de Jauss e a resume: segundo Jauss, Benjamin "não entende a dialética entre antigo e moderno, em particular o fato de que ‘antigo' não remete mais, em 
Baudelaire, ao paradigma da Antiguidade mas, sim, ao par obsoleto-novo; por isso Benjamin criticaria a ausência em Baudelaire de uma confrontação teórica mais apurada com a arte da Antiguidade, enquanto tal ausência é devida a uma mudança de paradigmas teóricos, segundo Jauss. Nas suas análises, Benjamin sublinharia o apego de Baudelaire a uma imagem idealizada de natureza e sua aversão pela grande cidade, insistindo na crueldade da modernidade sem perceber os traços positivos desse conceito em Baudelaire. Curiosamente, Jauss deduz esse mal-entendido da postura marxista de Benjamin, que queria ler a obra de Baudelaire como uma denúncia do capitalismo e não como uma descrição positiva da emergência da modernidade" (GAGNEBIN, 1997, p. 148).

Seguindo a sugestão de Gagnebin, seria possível afirmar, contra Jauss, a descoberta por Benjamin de uma modernidade mais multifacetada em Baudelaire. Ele não censura a teoria da modernidade em nome de uma crítica marxista do capitalismo moderno, mas por sustentar que o moderno não diz respeito apenas ao louvor das descrições da cidade moderna, mas também a um registro mais agudo da busca do novo como a temporalidade ameaçadora que rege esta época. "A modernidade assinala uma época; designa, ao mesmo tempo, a força que age nessa época e que a aproxima da antigüidade" (BENJAMIN, 1991b, p. 80; 1999, p. 585). O novo é essa força que, ao mesmo tempo que configura a modernidade, dando-lhe um caráter único diante do existente, transforma-a imediatamente no seu oposto, a antiguidade. Benjamin tem em mente uma certa apreensão aguda do tempo que transforma cada vez mais rapidamente o moderno em antigo e o novo em velho. O tempo torna-se assim a experiência fundamental de tal arte que se rege pela busca do novo. Não é na crítica, porém, que o novo é apreendido na sua mais forte relação com antiguidade: "Nenhuma das reflexões estéticas da teoria baudelairiana expõe a modernidade em sua interpenetração com a antigüidade como ocorre em certos trechos de As Flores do Mal" (BENJAMIN, 1991b, p. 81; 1999a, p. 585). É nesses poemas que ambas se cruzam pela marca do novo: é na transitoriedade que a modernidade se apresenta mais intimamente ligada à antiguidade. Nas Flores do mal, tal consciência do tempo recebe o nome de spleen, marca da busca do novo e da contradição envolvida em tal busca: "O spleen interpõe séculos entre o momento presente e o que acabou de passar. É o spleen que incansavelmente gera 'antigüidade'. E, de fato, em Baudelaire, a modernidade não é outra coisa que a "mais nova antigüidade" (BENJAMIN, 1999c, p. 423).

De acordo com estas indicações, é possível então reconhecer a interpenetração mais íntima da modernidade com a antiguidade em poemas como "O cisne", em que Baudelaire faz o registro do exílio no interior de uma Paris em reconstrução sob os auspícios do projeto de reurbanização efetuado 
pelo Barão Haussmann. O crescimento urbano e econômico havia colocado a antiga Paris sob tal pressão que as ruas tortas e estreitas se colocavam como obstáculo ao desenvolvimento. Além disso, em revoltas populares, essas ruelas eram facilmente obstruídas por barricadas, como a lembrança recente dos conflitos de 1848 ainda testemunhava. Sob o eufemismo de embelezamento estratégico, bairros inteiros desapareceram e antigos pardieiros foram substituídos por amplas praças, jardins e alamedas, num violento processo de modernização que terminaria por reformular inteiramente a cidade. No momento em que Baudelaire inicia o poema, imagens da antiga Paris acompanham o poeta que passeia pelos novos quarteirões.

$I$

Andrômaca, eu penso em você! Esse pequeno rio, Pobre e triste espelho onde outrora resplendia

A imensa majestade de suas dores de viúva,

Esse Simeonte mentiroso que aumenta com teu pranto,

Fecundou subitamente minha memória fértil,

Quando eu atravessava o novo Carrossel.

A velha Paris não existe mais (a forma de uma cidade

Muda mais rápido, ah! que o coração de um mortal);

Só em espírito vejo todo esse campo de barracos,

Essas pilhas de capitéis esboçados e de cornijas,

Os gramados, os grandes blocos esverdeados pela água das poças,

$\mathrm{E}$, brilhando no ladrilho, a confusão de quinquilharias.

Lá era exposta outrora uma feira de animais;

Lá eu vi, numa manhã, quando sob o céu

Frio e claro o Trabalho acorda, onde a sujeira

Impele um furacão sombrio no ar silencioso,

Um cisne que escapara de sua jaula,

E, esfregando seus pés espalmados sobre o pavimento seco,

Sob o sol áspero arrastava sua plumagem branca.

Junto a regato sem água, o animal abrindo o bico

Banhava nervosamente suas asas na poeira,

E dizia, com o coração cheio de seu belo lago natal:

"Água, quando cairás? quando soarás, raio?"

Eu vejo esse infeliz, mito estranho e fatal,

Em direção ao céu às vezes, como o homem de Ovídio,

Em direção ao céu irônico e cruelmente belo,

Sobre seu pescoço convulsivo esticando seu rosto ávido,

Como se lançasse uma censura a Deus!

(BAUDELAIRE, 1976a, p. 85-86) 
A região atravessada pelo poeta, do Jardim das Tulherias ao Louvre, era antigamente coberta por casebres e pardieiros, e ponto de reunião de barracas de vendedores ambulantes e de mercadores de pássaros. Durante as reformas, esse enorme quarteirão foi inteiramente demolido e cedeu lugar à imponente esplanada dos dias de hoje. Cruzando esses espaços recém-inaugurados, Baudelaire não os descreve, mas os torna visíveis na justaposição das duas marcas da cidade moderna, o exílio e a transitoriedade. A presença da nova cidade pode ser lida na característica das figuras evocadas, seja a exilada Andrômaca da antiguidade, seja a imagem da decadência dos antigos quarteirões, seja a figura do cisne. Os três elementos lhe dão o fundamento de uma crítica que incide diretamente sobre as forças que agem no presente da cidade: não apenas a transformação, mas a sugestão de que essa transformação é um movimento de autodissolução. Assim, sob a constatação de que a antiga feição da cidade desapareceu - A velha Paris não existe mais —, surge o desvendamento da lei dessa transformação - (a forma de uma cidade/muda mais rápido, ah! que o coração de um mortal) — colocada entre parênteses, tanto para salientar que tal descoberta é incisiva demais para ser expressa abertamente, quanto porque a transformação triunfante da cidade, sua aparência moderna, procura esconder a relação subterrânea — a transitoriedade — que ela mantém com a antiga cidade. $\mathrm{O}$ caráter sólido e inabalável da cidade é duplamente afetado pela sua equiparação metafórica. A cidade torna-se fluida e volúvel, sujeita a transformações e influências sem previsão, e, mais incisivamente, abre mão de uma existência eterna. O mortal indica aqui a descoberta de que a Paris triunfante do império de Napoleão III está tão próxima da decadência e do desaparecimento quanto a velha Paris. Pode-se dizer que Paris continuaria a existir, mas que numa sucessividade de formas transitórias e de movimentos de destruição e construção. Baudelaire transporta assim para a transformação da cidade o mesmo paradoxo da produção do moderno, que nasce sob o signo de sua própria caducidade.

Essa descoberta da dissolução da cidade nos versos 7-12 funciona como uma articulação para a evocação das duas figuras do exílio. Andrômaca e o cisne reúnem-se no poema a partir de um ponto preciso, a memória do poeta solitário situado na nova Paris. A disparidade entre as duas figuras torna-se plausível pelo caráter destrutivo da cidade. Se os dois são registrados sob o ângulo do exílio é porque a nova cidade, ou o movimento de transformação que a produziu, é incapaz de acolher qualquer um dos dois. Assim, o movimento de produção do novo, direcionado ao futuro, tem como único passado os destroços que o poema recupera como ruínas da cidade antiga em processo de ser substituída pela nova. No processo de produção de uma modernidade já destinada à extinção, 
não há espaço para qualquer reflexão e retomada do passado. Assim, o exílio de Andrômaca pode ser lido como o exílio de uma tradição histórica e literária que ela representa e que não pode ser acolhida no espaço da cidade. A mesma expulsão ocorre com o cisne. Ele indica tanto a expulsão da vida orgânica pelo processo de urbanização e transformação em concreto de todo o ambiente como é uma alegoria de todos os exilados sem lugar na cidade. Sua figura indicadora de graça e delicadeza é incompatível com a agressividade do ambiente urbano. Como representação do exílio ele é a imagem da inadequação a uma cidade que se mostra como abandono e isolamento.

$\mathrm{Na}$ segunda parte do poema, há uma retomada dos elementos dispersos da primeira; articulando seus elementos, Baudelaire insiste na transformação poética daqueles dados apreendidos pela memória. A alegoria, de que o poeta é consciente, é uma indicação do sentido de perda e alienação que se instaura entre o poeta e as imagens da cidade.

II

Paris muda! mas nada na minha melancolia

Mudou! palácios novos, andaimes, blocos,

Velhas alamedas, tudo para mim se torna alegoria,

E minhas caras lembranças são mais pesadas que rochas.

Também diante do Louvre uma imagem me oprime:

Eu penso em meu grande cisne, com seus gestos loucos,

Como os exilados, ridículo e sublime,

E roído por um desejo sem trégua! e a seguir em você,

Andrômaca, derrubada dos braços de um grande esposo,

Gado vil, sob a mão do soberbo Pirro,

Ao pé de um túmulo vazio em êxtase curvada;

Viúva de Hector, ah! e mulher de Heleno!

Eu penso na negra, emagrecida e tísica,

Pisando na lama, e procurando, com o olhar alucinado,

Os coqueiros ausentes da soberba África

Atrás da imensa muralha do nevoeiro;

Naqueles que perderam o que não se pode reencontrar

Jamais, jamais! naqueles que bebem das lágrimas

E mamam da Dor como uma boa loba!

Nos magros órfãos que secam como uma flor!

Assim na floresta em que meu espírito se exila

Uma velha Lembrança soa como o pleno sopro de uma trompa!

Eu penso nos marinheiros esquecidos numa ilha,

Nos prisioneiros, nos vencidos!... e em muitos outros ainda!

(BAUDELAIRE, 1976a, p. 86-87) 
A sucessividade das lembranças da primeira parte cede seu lugar ao congelamento da realidade pelo olhar alegórico. Como colocou Jean Starobinski em sua interpretação do poema, há um espelhamento entre os versos 7-12 da primeira parte e a primeira estrofe da segunda por meio da autorreflexão do poeta melancólico (STAROBINSKI, 1989, p. 61). Se antes se indicava o movimento vertiginoso da transformação de Paris na contraposição entre a percepção imediata do poeta e as imagens que ela evocava, na segunda parte, há a imobilização desse movimento na justaposição da nova e da velha Paris sob a figura da ruína. Não é de outra forma que Paris surge no poema. Os novos palácios e as velhas alamedas convivem lado a lado em meio a blocos de pedra e andaimes que servem tanto à destruição quanto à construção da cidade. Como Benjamin afirma em seu livro sobre o barroco alemão, "como ruína, a história se fundiu sensorialmente no cenário. Sob essa forma a história não constitui um processo de vida eterna, mas de inevitável declínio" (BENJAMIN, 1984, p. 200; 1999a, p. 353). Qualquer sentimento de estabilidade cede sob a representação da ruína. Nela, o significado da cidade não surge como um monumento à eternidade, mas como aprofundamento da transitoriedade e da sujeição ao perecimento.

A figuração do novo como ruína ocorre no contexto da reabilitação da alegoria por Baudelaire, a qual permite que a nova Paris seja transposta para o poema como uma alegoria da transitoriedade. Os leitores de Benjamin reconhecem aí uma retomada de suas reflexões sobre a alegoria no drama barroco alemão. Ele reconhece, contudo, que os motivos da reabilitação da alegoria por Baudelaire são bem distintos daqueles que se impunham aos dramaturgos barrocos. Susan Buck-Morss, em seu estudo sobre o "projeto das passagens" de Benjamin, aponta esta diferença. "No estudo sobre o Drama Barroco, Benjamin havia argumentado que a alegoria barroca era a forma de percepção própria de uma época de ruptura social e guerra prolongada, em que o sofrimento humano e a ruína material eram matéria e forma da experiência histórica. Daí que o retorno da alegoria poderia ser interpretado como uma resposta à horrenda destruição da Primeira Guerra Mundial. Mas a experiência história que deu origem a Les fleurs du mal não era comparável. Em meados do século XIX, Paris, tempo e lugar em que os poemas de Baudelaire haviam sido escritos, estava no ponto mais alto de um desenvolvimento material sem precedentes. (...) Com certeza, os dias sangrentos da revolução de 1949 proporcionavam uma imagem diferente. Mas esse momento de violência política não era o conteúdo dos poemas de Baudelaire. Ao contrário, precisamente o esplendor da fantasmagoria urbana recém-construída, com sua promessa de mudança-progresso despertava nele a resposta alegórica mais 
tipicamente melancólica” (BUCK-MORSS, 2002, p. 220). Não é necessário, entretanto, como faz a autora, recorrer à relação entre alegoria e mercadoria para explicar o uso da alegoria por Baudelaire. Se Benjamin deixou, no livro das passagens, indicações instigantes, porém inacabadas, a esse respeito, o esforço dos comentadores em reconstruí-las ainda não produziu um resultado satisfatório. Diante disso, a estratégia aqui é a de explorar as formulações disponíveis nos próprios ensaios sobre Baudelaire. Segundo a hipótese deste artigo, suas colocações associam o uso da alegoria por Baudelaire ao aprofundamento da percepção da transitoriedade que marca a modernidade dos poemas de As flores do mal. Seria ainda este emprego da alegoria como uma forma de percepção do tempo que singulariza tais poemas diante dos escritos teóricos do poeta.

A imobilização alegórica do tempo na imagem da ruína é, neste contexto, a exata antítese da busca incessante do novo que move o artista de $O$ pintor $d a$ vida moderna. É a maneira encontrada por Baudelaire para registrar a destruição e o perecimento que caracterizam as forças que agem nessa transformação, ou seja, a força de envelhecimento de uma modernidade que se engendra a todo momento como busca da novidade. Como disse Benjamin, "Aquilo que sabemos que, em breve, já não teremos diante de nós torna-se imagem. Provavelmente isso ocorreu com as ruas de Paris daquele tempo" (BENJAMIN, 1991b, p. 85; 1999, p. 590). Diante da inevitável caducidade que permeia todas as coisas, os objetos perdem seu valor próprio e se tornam matéria-prima para a transformação alegórica. Baudelaire registra nessa primeira estrofe a própria ilustração de apreensão pela poesia de uma realidade colocada sob o signo do declínio. Ao interpretar o poema, Benjamin escreve: "Não é à toa que se trata de um poema alegórico. Essa cidade tomada por constante movimentação se paralisa. Torna-se quebradiça como o vidro, mas, também como o vidro, transparente - ou seja, transparente em seu significado. '(A forma de uma cidade/Muda mais rápido, ah! que o coração de um mortal.)'. A estatura de Paris é frágil; está cercada por símbolos da fragilidade. Símbolos de criaturas vivas (a negra e o cisne); e símbolos históricos (Andrômaca, 'viúva de Heitor e... mulher de Heleno.') O traço comum aos dois é a tristeza pelo que foi e a desesperança pelo que virá. Nessa caducidade, por último e mais profundamente, a modernidade se alia à antigüidade. Sempre que aparece em As Flores do Mal, Paris carrega essa marca" (BENJAMIN, 1991b, p. 81; 1999, p. 585-586).

A força de destruição do desenvolvimento urbano moderno foi representada várias vezes como o desejo de ver as grandes cidades modernas tais como ruínas da antiguidade. Alguns testemunhos, que Benjamin recolhe na sua afinidade com 
o projeto de Baudelaire de revelar a antiguidade no interior da modernidade, revelam o pressentimento de uma ameaça que paira sobre a cidade moderna, e que poderia, de um golpe, reduzi-la em ruínas comparáveis àquelas em que se transformaram as cidades antigas. Benjamin registra as declarações de Léon Daudet, que, ao contemplar Paris de um ponto elevado, teve consciência da ameaça e da destrutividade que pairava sobre grandes aglomerações urbanas como Paris, ao mesmo tempo que se surpreendia que tais cidades, apesar disso, ainda continuam a existir; e de maneira mais explícita, Benjamin reproduz a descoberta por Maxime du Camp da lei da inevitável decadência de todas as coisas humanas ao imaginar a moderna Paris subitamente transformada nos destroços de uma cidade antiga. A ideia de apresentar Paris como sujeita a essa inevitável destruição foi levada a termo pelas águas-fortes de Meryon, sobre o qual Baudelaire escreveu um entusiasmado texto. Suas vistas de Paris em águas-fortes foram feitas antes da reurbanização. Seu talento consistiu em ter mostrado o lado antigo desse presente figurado, como se, sob o seu olhar, surgisse já a Paris vítima da destruição a que estava destinada. "Ninguém se impressionou tanto com elas quanto Baudelaire. Não era a visão arqueológica da catástrofe, base dos sonhos de Hugo, aquilo que realmente o movia. Para ele a antigüidade deveria surgir de um só golpe de uma modernidade intacta, tal qual uma Atena da cabeça de um Zeus intacto. Meryon fez brotar a imagem antiga da cidade sem desprezar um só paralelepípedo. Era essa visão da coisa à qual Baudelaire continuamente se entregara na idéia de modernidade" (BENJAMIN, 1991b, p. 85; 1999, p. 590).

No poema "O cisne", Baudelaire reconhece o seu tema na força destrutiva da modernidade ao mesmo tempo que protesta contra ele. Como percebeu Starobinski, a constatação melancólica "Paris muda", como toda experiência melancólica, é acompanhada por uma acusação. Dessa forma, as contínuas destruições e reconstruções do urbanismo de meados do século XIX, com sua mistura de monumentalidade e função repressiva, encontram-se entre as causas do spleen e do sentimento de exílio que caracteriza o poema (STAROBINSKI, 1989, p. 64). A solidariedade do poeta com os exilados é o mais forte argumento a favor do protesto histórico-social. A recorrência do "eu penso" da segunda metade do poema põe a seu serviço uma consideração sobre a situação daqueles que o poeta retrata. Desde sua primeira aparição, na evocação da exilada Andrômaca logo na primeira estrofe, ele não é um "eu penso" absolutizado, a-histórico e isolado, que pudesse, por si mesmo, instaurar o tempo do poema, mas uma consideração pensativa e atormentada sobre o sofrimento dos exilados compartilhado pelo poeta. O movimento do pensamento não se limita à atribuição de um sentido alegórico às figuras 
visíveis, mas procura, sobretudo, reuni-los no conjunto de exilados que permanece em aberto (STAROBINSKI, 1989, p. 76). As últimas estrofes não procedem apenas por uma enumeração de figuras homólogas. Há, sim, uma justaposição de figuras exemplares - a negra, os órfãos, os vencidos, os esquecidos — abarcadas pelo sentimento de fraternidade do poeta. A abertura final não fecha a lista dos exilados, mas indica que muitos ainda se encontram sob esse signo fatal operado pela modernidade.

Como indicam os últimos versos do poema, o poeta não foge à caracterização de exilado. Assim, ele faz parte da figura do cisne que alegoriza a série sem fim dos exilados (da modernização, do progresso, das esperanças malogradas de 1848). O cisne que empoeira suas asas e se bate nas pedras da cidade é uma alegoria de todos os exilados, e dessa forma também do próprio poeta. A imagem do pássaro privado do vôo era cara a Baudelaire para representar a inadequação do artista na sociedade que envolve e sustenta a transformação de Paris. A contradição é a sua própria definição na caracterização antitética de ridículo e sublime. Nesse mundo, não há espaço para a satisfação e apaziguamento de seus desejos ("Roído por um desejo sem trégua"). O mesmo tema do pássaro exilado está num dos primeiros poemas de As flores do mal. Em "O albatroz", a incompatibilidade entre o poeta e o mundo está registrada na contraposição entre a majestade do pássaro durante o voo e a situação degradante ao descer para junto dos marinheiros do navio que ele acompanhava do alto. O paradoxo é o próprio modo de expressão dessa situação contraditória.

Tão logo os colocam sobre o assoalho,

Esses reis do azul, desajeitados e envergonhados,

Deixam lamentavelmente suas grandes asas brancas

Arrastar como remos ao lado deles.

Esse viajante alado, como é desajeitado e fraco!

Ele, outrora tão belo, como é cômico e feio.

(BAUDELAIRE, 1976a, p. 9-10)

A mesma contradição atravessa o poeta no momento em que se infiltra na multidão. A alegoria da inadequação do artista é explicitada na última estrofe:

O Poeta é semelhante ao príncipe das nuvens

Que enfrenta a tempestade e se ri do arqueiro;

Exilado sob o sol em meio a vaias,

Suas asas de gigante o impedem de andar.

(Idem) 
A imagem do exílio em Baudelaire é tão mais contundente quanto mais ela se insere no contexto da vida urbana. Como representação da alienação urbana, o exílio é a figura da destrutividade presente nas forças históricas que configuram a modernidade de Baudelaire.

Estes elementos permitem ainda a Benjamin compreender a obra de Baudelaire como a exposição de uma mudança decisiva na composição da experiência histórica. Segundo as reflexões de seu ensaio "Sobre alguns temas em Baudelaire", o que estrutura a verdadeira experiência (Erfahrung) é uma especial conjunção, na memória, entre traços do passado individual e do passado coletivo. A experiência está condicionada à atividade de rememoração que instaura a possibilidade de que o passado individual se insira no contexto mais amplo da comunicação entre gerações sucessivas que formam a tradição. A rememoração, para estabelecer essa conjunção, necessita, por sua vez, de uma noção plena de tempo capaz de estruturar uma concepção decisiva de presente que se descubra na sua possibilidade de entrar em contato com o passado e retomar experiências que esse passado lhe transmite. Mas essa retomada só é possível caso o presente reflita sobre essa distância fundamental que o separa e o torna diferente do passado. Somente assim se pode entender a noção de atualização do passado no presente, que reelabora a experiência passada, mas não anula a diferença do presente em relação a ela. A constituição da experiência pela atualização do passado remete a uma noção complexa de tempo presente. Sendo uma tarefa do presente constituir uma relação produtiva com o passado, a experiência não é assim um tempo pleno que se desenrola do passado ao futuro, formando uma continuidade. Ela é, isso sim, uma descontinuidade, uma atividade que tem que ser reiterada a cada momento, uma retomada que não ocorre automaticamente. Tal contato está sempre sujeito ao perigo e ao risco envolvidos no processo de transmissão da cultura. A rememoração é, portanto, uma atividade de reencontro de passado e presente enquanto articulação de uma diferença produzida pelo distanciamento. É a reiteração desse reencontro que estrutura a experiência.

O poema "O cisne", analisado a partir das considerações de Benjamin no ensaio A modernidade, fornece um registro do declínio desta concepção forte de experiência. A cidade não é o espaço de sociabilidade capaz de integrar seus habitantes em uma experiência comum. Ela também não permite o contato com a tradição, como se pôde perceber pela figura de Andrômaca. Por fim, o instrumento de reunião da tradição com a memória dos exilados, ou seja, a memória do poeta, também não é capaz de registrar uma experiência comum. Muito pelo contrário, o curso acelerado do tempo, que consome rapidamente o presente e impede que ele atualize o passado, e o exílio do poeta, sinal 
do reconhecimento de sua própria alienação frente à cidade, são índices da insuficiência de sua atividade rememorativa. Além disso, sua memória não é suficiente para estabelecer uma correspondência entre os elementos recordados; eles permanecem sujeitos à recordação aleatória do poeta que se desenrola num movimento aparentemente sem fim. O único vínculo que o poeta consegue estabelecer entre eles é negativo: é o exílio em face de uma situação historicamente configurada, ou, em outras palavras, a impossibilidade de construir uma experiência nas condições históricas da produção incessante do novo que sustenta a modernidade.

Diante da modernização violenta, o poeta assume a tarefa de problematizar sua inserção histórica. Ao mesmo tempo que lamenta o infortúnio daqueles que considera seus irmãos, faz o registro mais agudo das forças históricas produtoras da alienação. Sob o olhar do spleen, o progresso triunfante mostra sua face decadente. Como um dos exilados, o poeta consegue, por um estranhamento da percepção habitual, registrar na imobilização de um momento a última novidade em seu estado de ruína. A ruína é concretização dessa justaposição de antigo e moderno, identificada por Benjamin como o desejo de Baudelaire em revelar a face antiga da modernidade. "Baudelaire quer ser lido como um escritor da antigüidade. Essa pretensão foi satisfeita espantosamente rápido. Pois o distante futuro, as 'époques lointaines' (...) chegaram; e tantos decênios após sua morte quanto Baudelaire imaginaria séculos. Decerto Paris ainda está de pé; e as grandes tendências do desenvolvimento social ainda são as mesmas. Porém o fato de terem permanecido estáveis torna mais frágil, em sua experiência, tudo que esteve sob o signo do 'verdadeiramente novo'. A modernidade é o que fica menos parecido consigo mesmo; e a antigüidade - que deveria estar nela inserida - apresenta, em realidade, a imagem do antiquado" (BENJAMIN, 1991, p. 88; 1999b, p. 593).

Em função desse quadro, é possível salientar a diferença de Benjamin em relação a interpretações mais recentes da poesia de Baudelaire, muitas das quais reivindicam a continuidade de seu trabalho. Um caso exemplar é o de Dolf Oehler, que em diversos livros - Quadros parisienses, O velho mundo desce aos infernos e Terrenos vulcânicos — realizou um trabalho singular de crítica materialista dos escritos de Baudelaire, ao destacar o papel da Revolução de 1848 na obra do poeta. Não é o caso de retomar sua análise em detalhes, mas apenas de ressaltar um ponto específico com o intuito de marcar sua diferença em relação a Benjamin. Esta estratégia permitirá desenvolver a hipótese segundo a qual o conceito de experiência de Benjamin, desenvolvido a partir da relação entre spleen e ideal, fornece uma conexão mais eficaz entre modernidade e crítica social do que aquela proposta por Oehler. Espera-se 
assim ressaltar a especificidade da leitura de Benjamin tanto diante daqueles que o criticam pelo "marxismo" de sua análise (Jauss), quanto em função de leituras de cunho explicitamente marxista, como a de Oehler.

Oehler retoma a definição de Benjamin de experiência — "Onde há experiência no sentido estrito do termo, entram em conjunção, na memória, certos conteúdos do passado individual com outros do passado coletivo" (BENJAMIN, 1991a, p. 107; 1999b, p. 611) — para explicitar o teor social da poesia de Baudelaire. Sua tese central é a de que tal experiência poderia ser recuperada pela rememoração coletiva dos massacres de junho de 1848 . O trabalho sobre o recalque que marca a conjunção da vida individual com o passado coletivo assinalaria a possibilidade de produção da verdadeira experiência no presente do Segundo Império. Com isso, ele transforma a relação proposta por Benjamin entre spleen e ideal. Se em Benjamin o spleen se refere à dissolução da experiência nas condições de vida do XIX e o ideal à rememoração dessa experiência perdida, em Oehler essa dualidade entre spleen e ideal é reorganizada da seguinte forma: os poemas spleen se dedicariam ao trabalho de crítica de uma sociedade que recalcou um passado incômodo, sendo que a rememoração do massacre seria condição decisiva para a possibilidade da crítica. Já o ideal, que em Benjamin se refere, sobretudo, à rememoração de algo irremediavelmente perdido, transforma-se em utopia, em possibilidade futura de uma reconciliação final entre homem e natureza (OEHLER, 1997, p. 98-99 e 190-193).

Como se vê, Oehler inverte a maneira como Benjamin trabalha a dualidade fundamental de Baudelaire, a partir da consideração de 1848 como o centro dessa poesia. Mas isso ao preço de uma extensão da importância de 1848 para todos os âmbitos das transformações ocorridas em Paris, bem como pela diminuição da importância de outros aspectos que se envolveriam em tais circunstâncias históricas. Não há como negar que 1848 tenha um papel decisivo também para a leitura de Benjamin. Muitas passagens de seus textos o comprovam. Apesar disso, 1848 não esgota sua análise da modernidade parisiense, e nem se constitui a única chave para a interpretação de Baudelaire. Em Benjamin, essa data é um dos elementos de uma abordagem que procura entender Baudelaire, e a experiência fundamental da oposição entre spleen e ideal, no contexto mais amplo da transformação da vida urbana e da cultura sob o impacto do desenvolvimento do capitalismo em meados do século XIX.

Ao remeter a experiência do ideal para o futuro, Oehler enfraquece a oposição com o spleen. Como foi dito, ele remete ao spleen tanto a crítica social ao Segundo Império como o esforço de rememorar 1848. Caso o recalque da revolução fracassada fosse superado, seria possível estabelecer 
uma experiência no sentido estrito do termo. É à literatura que Oehler confere essa tarefa como autorreflexão da época e reação à substituição da memória dos massacres de 1848 pela crença no progresso econômico do império de Napoleão III. Em Benjamin, a experiência também se funda na rememoração, mas essa está situada no ideal e não no spleen, o que traz consequências decisivas para a tarefa de rememorar o passado. Se no ideal há a tentativa de representar traços de uma experiência original, no spleen há o registro da impossibilidade de sucesso de tal esforço diante das condições de vida do capitalismo do século XIX. Há uma relação de tal forma intrínseca entre esses dois termos que cada um fornece a crítica do outro, sendo que os dois são maneiras antitéticas de revolta contra uma mesma temporalidade destruidora. Se, no spleen, há uma consciência aguda na percepção do tempo como algo destruidor, algo que é revelador tanto das circunstâncias históricas que dão forma a esse sentimento como dos paradoxos que envolvem uma poesia que passa a se reger pela busca do novo, no ideal, há uma negação crítica dessas condições na forma da rememoração de uma experiência que não é mais possível numa grande cidade europeia do século XIX. Isso torna indissolúvel o vínculo entre a rememoração da experiência do ideal e as condições históricas do spleen. A inseparabilidade entre ambos significa não só que é o empobrecimento da experiência sob determinadas condições históricas que gera a busca por uma experiência plena e irrealizável, mas também que é somente no momento de crise de tal experiência que seus traços fundamentais tornam-se perceptíveis.

Por fim, o fundamento da crítica que Baudelaire dirige à modernidade deve ser investigado na própria relação estabelecida por Benjamin entre o spleen e os termos constitutivos da experiência, ou seja, memória e distanciamento. No spleen, a memória individual não possui uma contrapartida na experiência coletiva, e o tempo dissolve o presente na sua capacidade de refletir sobre a distância que o separa do passado, inviabilizando a construção de uma experiência a partir da contraposição entre passado e presente. Mas, num contexto de busca incessante do novo, no qual toda a atenção está voltada ao instante seguinte, a contraposição entre passado e presente assume uma outra função. Essa função é aquela assumida pelo spleen em "O cisne". O olhar alegórico do poeta não atualiza o passado na realização de uma experiência no presente, mas se vale da memória do passado para imobilizar a temporalidade que consome o presente.

O resultado desse trabalho é a apreensão da cidade na imagem de uma ruína, que explicita a força de destruição responsável por transformar cada vez mais rapidamente o presente em passado. A imobilização do tempo em 
uma imagem alegórica historiciza a aparência de eternidade que a crença no progresso confere à cidade. O spleen possibilita ao poeta a reflexão sobre a dissolução histórica do distanciamento entre passado e presente e do enfraquecimento da memória no sentido da rememoração. Sob esse viés, o spleen reconhece a impossibilidade da experiência por meio do empobrecimento da memória e do distanciamento. Isso não significa, portanto, o abandono das questões concernentes a esses dois termos, mas a sua problematização sob o viés de uma realidade histórica marcada pela crise da experiência. A tensão com essas duas condições da experiência torna-se responsável pela consciência histórica do spleen. O que pauta o passeio pela cidade em "O cisne", e que transparece na consciência aguda do curso do tempo, é a reflexão sobre a historicidade da experiência e de sua impossibilidade no momento histórico de constituição da modernidade. A imagem da modernidade que se expõe no spleen é, assim, tanto a do declínio da experiência quanto a da profunda consciência histórica desse momento de crise.

Benjamin chamou a atenção para o fato de que, no spleen, Baudelaire ainda dispõe de estilhaços da verdadeira experiência histórica (BENJAMIN, 1991a, p. 137; 1999b, p. 643). É a consciência histórica do declínio da experiência que lhe garante apanhar esses fragmentos. $\mathrm{Na}$ experiência, o sujeito que atualiza no presente o passado reflete antes de tudo sobre sua própria situação histórica; o passado com o qual ele se comunica na rememoração the vem à presença trazendo as marcas da distância que os afasta. Essas marcas indicam a importância do passado para a constituição do presente que o recorda. É do significado do passado para o presente que se origina a reflexão histórica do sujeito da experiência. O distanciamento é, portanto, o que possibilita a consciência histórica na experiência. Como reflexão sobre o próprio presente, o distanciamento é algo que se interpõe também entre o sujeito e seu presente. Isso ocorre uma vez que o presente não é apreendido em uma imediatez entre o sujeito e a experiência coletiva. A relação com o presente é mediada pela reflexão do sujeito sobre o seu próprio passado, pela relação desse passado com um passado coletivo, e pela possibilidade de atualização da relação entre passado individual e passado coletivo no presente. Em outros termos, a relação do indivíduo com seu tempo presente é mediada pela tradição. Nenhum outro termo define melhor a compreensão de Benjamin de uma experiência coletiva. Como algo que se atualiza no presente, a tradição não é um monumento ao qual o presente presta reverência, mas a transmissão de uma experiência entre passado e presente. Na modernidade, o contato com a tradição está atrofiado. Mas, se a reflexão sobre o próprio presente não é capaz de atualizar a tradição, ela ainda é possível como consciência histórica dessa impossibilidade. E aqui 
se mantém um aspecto da noção forte de distanciamento que caracteriza a experiência. Como reflexão sobre a sua inserção histórica no contexto da modernidade parisiense e sobre a impossibilidade da realização da experiência nessas circunstâncias, o poeta de "O cisne" retém os estilhaços da verdadeira experiência histórica a que se refere Benjamin. No spleen, o distanciamento se traduz na perspectiva crítica que o poeta mantém frente ao declínio da experiência.

\section{Referências}

BAUDELAIRE, Charles. Euvres Complètes I. Paris: Gallimard, 1976a. BAUDELAIRE, Charles. Euvres Complètes I. Paris: Gallimard, 1976b. BENJAMIN, Walter. Charles Baudelaire: Ein Lyriker im Zeitalter des Hochkapitalismus. In: Gesammelte Schriften I-2, Frankfurt am Main: Suhrkamp, 1999 b. BENJAMIN, Walter. Das Passagen-Werk. In: Gesammelte Schriften V. Frankfurt am Main: Suhrkamp, 1999c.

BENJAMIN, Walter. Obras escolhidas III: Charles Baudelaire, um lírico no auge do capitalismo. São Paulo: Brasiliense, 1991.

BENJAMIN, Walter. Origem do drama barroco alemão. São Paulo: Brasiliense, 1984.

BENJAMIN, Walter. Ursprung des deutschen Trauerspiels. In: Gesammelte Schriften I-1. Frankfurt am Main: Suhrkamp, 1999a.

BUCK-MORSS, Susan. Dialética do olhar: Walter Benjamin e o projeto das passagens. Belo Horizonte: Ed. UFMG; Chapecó: Ed. Universitária Argos, 2002.

GAGNEBIN, Jeanne Marie. Baudelaire, Benjamin e o moderno. In: Sete aulas sobre linguagem, memória e história. Rio de Janeiro: Imago, 1997.

JAUSS, Hans Robert. Literarische Tradition und gegenwärtiges Bewußtsein der Modernität. In: Literaturgeschichte als Provokation. Frankfurt am Main: Suhrkamp, 1970.

OEHLER, Dolf. $O$ velho mundo desce aos infernos: auto-análise da modernidade após o trauma de junho de 1848 em Paris. São Paulo: Companhia das Letras, 1999.

OEHLER, Dolf. Quadros parisienses: estética anti-burguesa em Baudelaire, Daumier e Heine (1830-1848). São Paulo: Companhia das Letras, 1997.

STAROBINSKI, Jean. Les figures penchées: "Le cygne". In: La melancolie au miroir: trois lectures de Baudelaire. Paris: Julliard, 1989. 